\title{
Decision Making to Select the Best Order Quantity (BOQ) from Supplier using Genetic Algorithm
}

\author{
Watheq H. Laith ${ }^{1}$, Swsan S. Abed Ali ${ }^{2}$, Mahmoud A. Mahmoud ${ }^{2}$ \\ Dept of Statistical, College of Adm and Econ., University of Sumer, Al-Refaee, Thi-qar, Iraq ${ }^{1}$ \\ Branch of Industrial Engineering, Dept of Production Engg and Metallurgy, University of Technology, Baghdad, Iraq ${ }^{2}$
}

\begin{abstract}
Manufacturers need to have a good supply chain management system in order to achieve low inventory levels, short lead times and adjustability to meet customer demands at minimal total operation cost. The most important drawback of existing methods used to minimize inventory costs as Just-in-time (JIT) methodology or to minimize transportation and order costs as Economic Order Model (EOQ). This minimization strategy may not be able to give the best order quantity because of the relationship between inventory cost and transportation cost, In this paper, we used genetic algorithm (GA) to reduce the inventory and transportation costs together to determine the Best Order Quantity (BOQ). The main advantage of this new method, it is covers pull system, push systems, short planning horizon, and long planning horizon.
\end{abstract}

Keywords: Economic Order Model (EOQ), genetic algorithm (GA), Best Order Quantity (BOQ) Just-in-time (JIT).

\section{INTRODUCTION}

Companies select Single or multiple suppliers to fulfill the Nouha and et al.(2014) Calculating the lot sizing depend demand, and replenishment order quantity is split into Economic Order Quantity (EOQ), and the second method different portions for each supplier at the same time. There is the Periodic Order Quantity method which is based on are two types of supplier selection problem. In the first the notion of orders economic period and calculated with type of supplier selection, a single supplier can fulfill the Wilson's formula[5].

entire buyer's demand. Only one decision should be made in this situation: which supplier is the best. In the other type of supplier selection, there exists no single supplier who can satisfy the entire buyer's needs. In this situation, the buyer has to split order quantities among suppliers for having a stable environment of competitiveness [1].

Davari and et al (2008) presented a multiple suppliers and multiple products model. There were three objectives to achieve, minimizing purchasing cost, rejected units and late delivered units [2].

Sarker and et al. (2008) consider EOQ-like batch sizing models that account for the possibility of rework being done during cycles, as well as after a certain number of cycles. Especially the latter deals with quite some fargoing issues and hence provides some useful insights. Nonetheless, the paper stresses the need for flawless production, since rework will always be more expensive than first-time right production [3].

Wadhwa and Ravindran (2010) introduced a multipeobjective multiple-supplier selection model for low risk and cost products. The first objective was to minimize the total purchasing cost, which concluded total variable cost, fixed cost, inventory holding cost and the bundling discounts. The second objective was to minimize the reject units under supplier capacity constraint. Shortage was not allowed and the multi-objective model was solved by preemptive goal programming [4].

\section{INTEGRATED PURCHASING AND SUPPLY MANAGEMENT PROCESS}

The supply management function has grown from a tactical function of purchasing/procurement into a key strategic role within organizations. Supply management exists to explore business opportunities and implement supply strategies that deliver the most value possible to the organization, its suppliers, and its customers. Strategic supply management is the organization's primary source for collecting market intelligence and developing costreduction programs. Given the strategic nature of the supply function, the top supply management professional is usually a member of the organization's senior management team. In this leadership role, supply management professionals must be knowledgeable and understand all areas of the business in order to develop strategies consistent with the organization's goals and successful business procedures.

The purpose of supply management is to support the transformation of raw materials and component parts into shipped or inventory goods. The function of inventory in general is to decouple the entire transformation process. During the transformation process, materials are combined with labor, information, technology, and capital. Figure (1) focus of integrated purchasing and supply management [6]. 


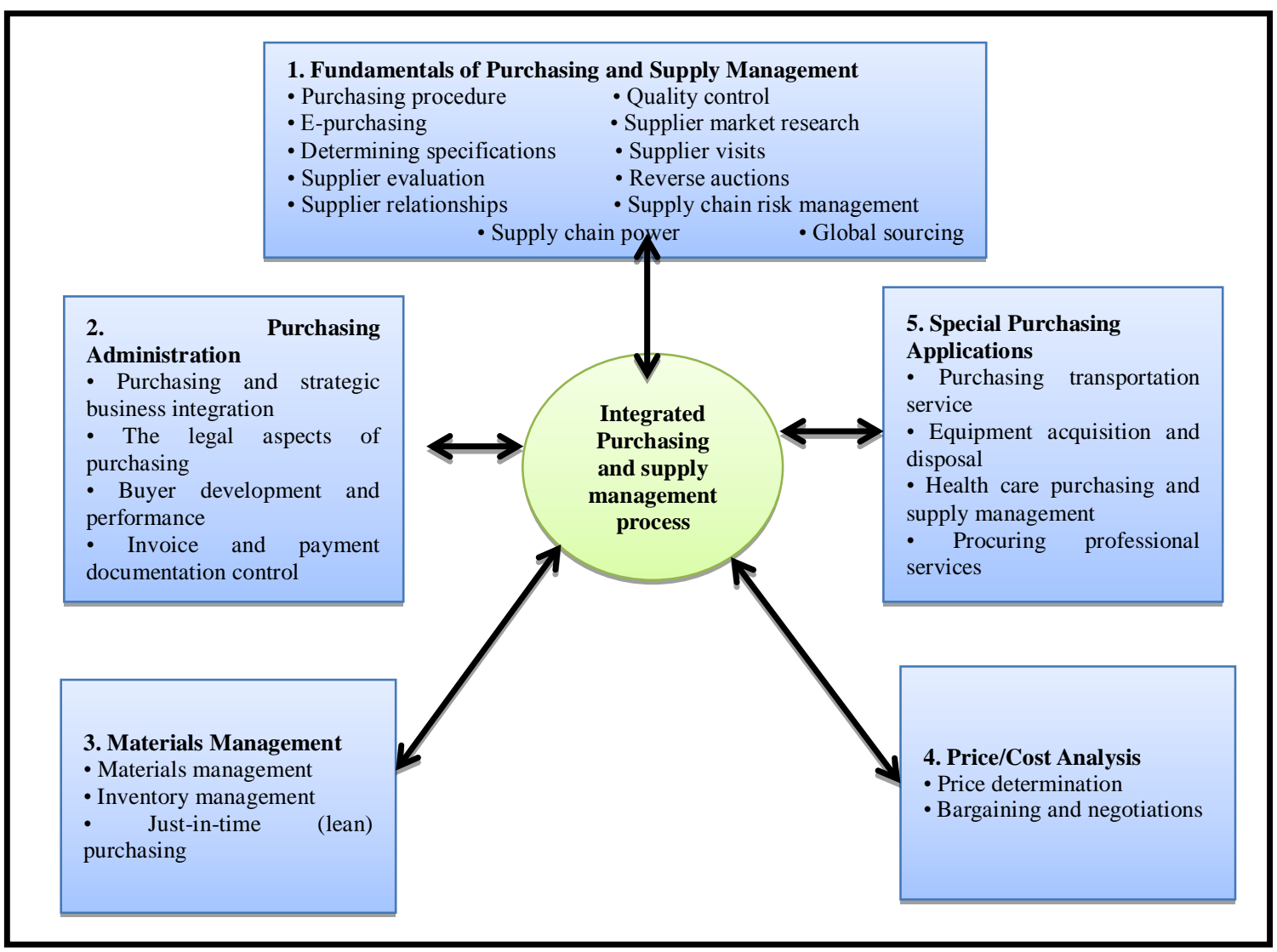

Figure (1) Integrated Purchasing and Supply Management Process [6]

\section{INVENTORY AND TRANSPORTATION COSTS}

The manufacturer needs to order the items to meet their demand targets at a minimal total cost. Each item has different known demand targets at different time points .It also has fixed cost for each order placed and fixed holding cost. For purchasing and shipping costs, the price is dependent on the number of items that would be order. The model determines the number of each item to be purchased, at each time point, to meet the demand targets at these time points, in order to minimize the total cost. Proposal model costs in this paper include as following:

\subsection{Order Costs}

The ordering costs is a fixed cost of tracking trucks from a supplier to inventory, labor costs of processing orders, inspection and returning of poor quality products [7].Conversly to the costs fixed per unit , the inventory costs fixed per order comprises only a porition of the acquisition cost of inventory. This is the cost incurred each time a stock replenishment order is placed and includes costs such as import duties, telphone calls, stock consolidator's fee, etc. Ordering cost was considered as a fixed component and part of other fixed costs [8].

\subsection{Holding Costs}

Holding cost define as the cost associated with having one unit in inventory for a period of time. [9]: The working of the (EOQ) is shown in figure (2), where a replenishment order of quantity $\mathrm{Q}$ is placed the moment the inventory reaches a level $R$. the virtual stock level consist of the sum of the on-hand inventory of a product currently stored at a location, and the inventory that is en route to that specific location.

In comparing the virtual stock level of the (EOQ) model to that of the JIT model, shown in figure (3), it can be seen that the JIT model's virtual stock level fluctuates far less than that of the (EOQ) model . It should also be noted that the average stock level of a product in the JIT methodology is very close to the maximum number of unit stored, compared to the (EOQ) model where the average stock level is almost half of the maximum number of unit stored . [10].

\subsection{Purchasing Costs:}

It is the primary concern of any manufacturing organization to get an item at the right price. But right price need not be the lowest price. It is very difficult to determine the right price; general guidance can be had from the cost structure of the product. [11].

\subsection{Transportation Costs:}

Transportation costs will at first decline as the number of facilities increase, but will eventually increase as the number of facilities increase as a result of inbound and outbound transportation costs. 


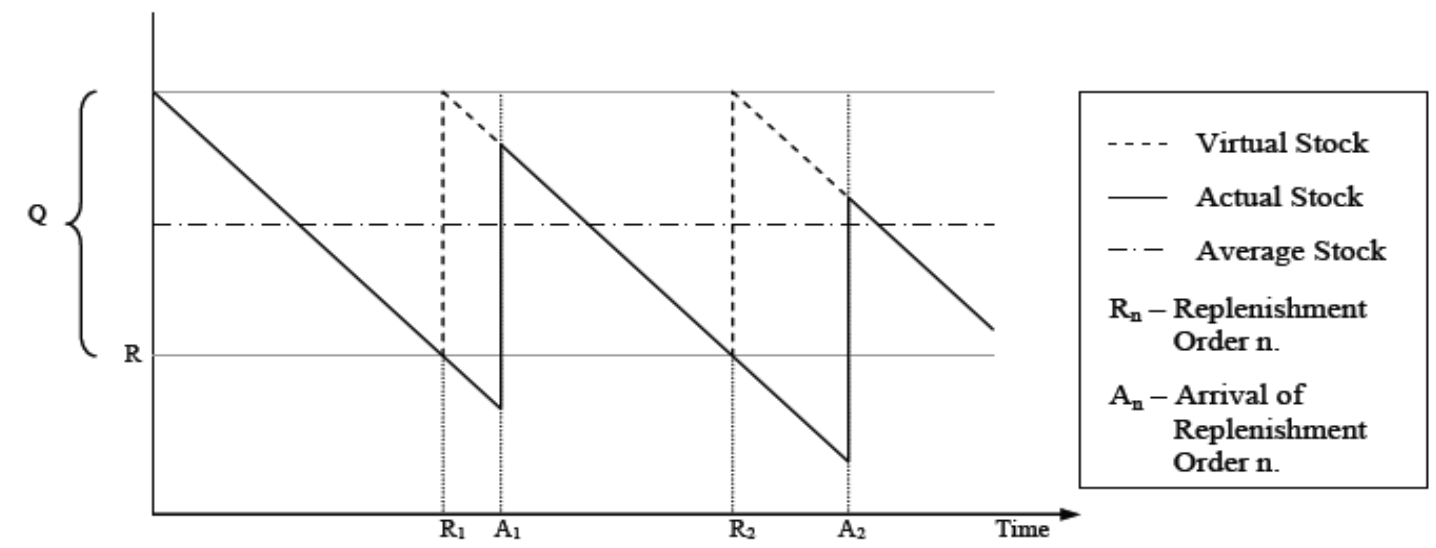

Figure (2) The fluctuation of inventory levels in the economic order quantity inventory control model [10].
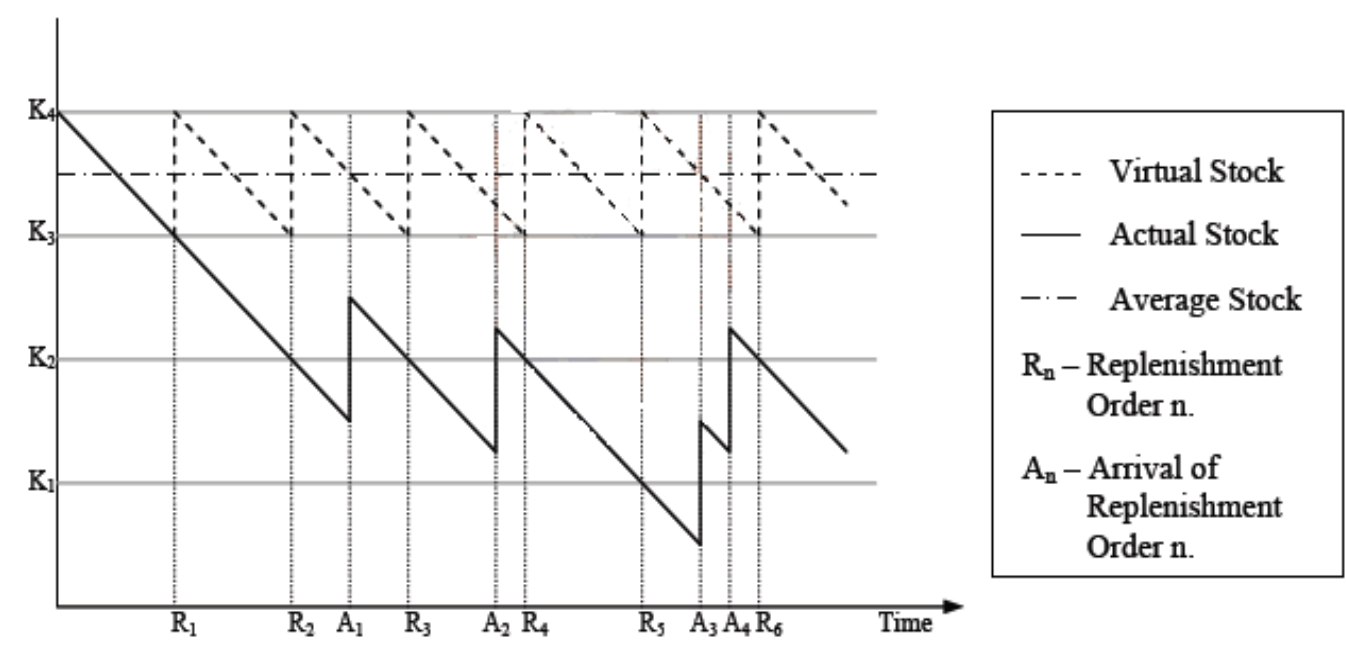

Figure (3) The fluctuation of inventory levels in the Just-In-Time inventory control model [10].

The total cost of transporting products must be measured achieving this goal, but it may not be the optimal solution. and not only the cost of moving the products to the The first reason is, in the JIT model the manufacturers warehouse. With fewer locations saving can be obtained order the items whenever they need to meet the demand by making use of bulk distribution from the manufacturer targets thus, it covers just pull systems and short planning or supplier. There will however be a certain point where horizon.

there are too many warehouses and fewer inventory of the Anew model covers pull system, push systems, short various item lines will have to be shipped to the planning horizon, and long planning horizon. In pull warehouse to ensure that there are no items that are systems the demand targets for items at each time point are overstocked [12]. know but may be non-constant during a planning horizon. The manufacturers respond the demand targets an

\section{THE PROPOSAL MODEL TO DETERMINE THE BEST ORDER QUANTITY}

Volatile customer expectations and rapidly changing The second reason is, by increasing order quantities, the markets cause short lifecycle items. Manufacturers need a price and shipping cost per item will be decreased, strategy to decrease the risk of short lifecycle items and to although in a JIT model, the price breaks for purchasing increase efficiency. Receiving the items from suppliers at and transportation costs may not happen at all time points. the same time of the demand target is one of the keys of Manufacturers need to have a good supply chain decreasing the risk for the manufacturers.

management system in order to achieve low inventory Just -In-Time (JIT) model is one of the ways for levels, short lead times and adjustability to meet customer 
demands at minimal total operation cost. This cost is made up of inventory and transportation costs that are often minimized separately. This minimization strategy may not be able to give an optimal order quantity because of the relationship between inventory cost and transportation cost. In this paper, inventory and transportation cost are minimize together to determine optimal order quantities.

\subsection{Assumptions:}

The assumptions that are:

1-Items are always available for shipment.

2- Each item has constant holding and ordering costs.

3 - The purchase and transportation costs are vary with order quantity.

4- The demand are known and non-constant.

5- The period between time points of planning horizon could be measured in hours, days, months, etc.

\subsection{Parameters and Variables}

We have a planning horizon with $\mathrm{n}$ time points, where the period between time point could be measured in hours, days, weeks, months or years, depending on the application . The set of all time points is $J=\{0,1,2,3, . ., n\}$ At time point $j \in J$, which is the beginning of time period $\mathrm{j}$ , item $i \in I$ has demand $D_{i}^{j}$ and inventory level $V_{i}^{j}$ where $\mathrm{i}$ is the index set of all items to be delivered by the supplier to the manufacturer and the initial inventory level $V_{i}^{0}$ is know .The plant warehouse has limited stock capacity for each item $i \in I$ depend on lower and upper number of units for all item.The inventory level of item at the beginning of time period $j \in J$ is:

$$
\begin{gathered}
V_{i}^{j}=V_{i}^{j-1}+Q_{i}^{j}-D_{i}^{j-1}, \forall j \in\{0\} \\
Q_{i}^{j} \geq 0, \text { and } Q_{i}^{0}=0, \quad \forall i \in I
\end{gathered}
$$

The inventory level of item $i$ should be greater than or equal to the demand at each time point $\mathrm{j}$ when there is no shortage in items, thus:

$$
V_{i}^{j} \geq D_{i}^{j}, \forall i \in I, \forall j \in J
$$

The price of each item decrease when the number of item increases. The purchasing cost of order quantity is:

$$
\text { ifLower } \leq D_{i}^{j}<\text { Upper then } P_{i}^{j}=p_{i}^{k} Q_{i}^{j} ; \forall i, j
$$

Where:

$P_{i}^{j}=$ Purchasing cost for item $\mathrm{i}$ in time $\mathrm{j}$.

$p_{i}^{k}=$ The set of price breaks of item $\mathrm{i}$, weher $\mathrm{k}=\{$

$1,2,3, \ldots$.$\} .$

The transportation cost for shipping the items decrease when the number of item increases. Transportation cost of order quantity is:

$$
\text { if }\left(\text { Lower } \leq D_{i}^{j}<\text { Upper }\right) \text { then } R_{i}^{j}=r_{i}^{m} Q_{i}^{j} ; \forall i, j(5)
$$

Where:
$R_{i}^{j}=$ Transportation cost for item $\mathrm{i}$ in time $\mathrm{j}$.

$r_{i}^{m}=$ The set of price breaks of item $i$, where $m=\{1,2,3,$.

The ordering cost for item $i$ at time point $j$ is:

$$
O\left(Q_{i}^{j}\right)=o_{i} Q_{i}^{j} ; \forall i, j
$$

Where:

$o_{i}=$ Ordering cost for item i.

The total ordering cost for during whole planning horizon is :

$$
O\left(q_{i}^{j}\right)=\sum_{i \in I} \sum_{j \in J} o_{i} q_{i}^{j} ; \forall i, j
$$

Item $\mathrm{i}$ has a unit holding $\cos \mathrm{h} \mathrm{h}_{\mathrm{i}}$ per time period. The total holding cost for storing order quantities of item $i$ between time points $\mathrm{j}$ and $\mathrm{j}+1$ is:

$$
H\left(Q_{i}^{j}\right)=h_{i} V_{i}^{j} ; \forall i, j
$$

The total holding cost for during whole planning horizon is :

$$
\sum_{i \in I} \sum_{j \in J} H\left(Q_{i}^{j}\right)=\sum_{i \in I}\left(h_{i} V_{i}^{0}+\sum_{j \in J} h_{i} V_{i}^{j}\right)
$$

Let $C\left(Q_{i}^{j}\right)$ be the total cost, that is the summation of purchasing, ordering, holding and transportation costs. Form equations (6),(7),(8) and (9) we have :

$C\left(Q_{i}^{j}\right)=\sum_{i \in I} \sum_{j \in J}\left(P\left(Q_{i}^{j}\right)+O\left(Q_{i}^{j}\right)=H\left(Q_{i}^{j}\right) R\left(Q_{i}^{j}\right)\right)(10)$

For finding the optimum $Q_{i}^{j}$, we need to minimize the total cost , $C\left(q_{i}^{j}\right)$. Thus, the model is to:

$$
\text { Minimize } \mathrm{Z}=C\left(q_{i}^{j}\right)
$$

Subject to:

$$
\sum_{j=0}^{J} Q_{i}^{j}+V_{i}^{0} \geq \sum_{j=0}^{J} D_{i}^{j} ; \forall i, j
$$

$Q_{i}^{j}>=0$ and integer variable

The genetic algorithm starts with an initial set of solutions which is known as a population. The individuals of the population are called chromosomes which are evaluated according to a predefined fitness function, in our case the total cost. Each chromosome include several genes.The gene represents an order quantity of item $\mathrm{i}$ at time point $\mathrm{j}$.

\subsection{Solution of the Model}

The genetic algorithm (GA) module in matlab's global optimization toolbox is used to solve equation (14); the 
genetic algorithm is a stochastic search method for solving existing population through crossover and mutation [13]. both constrained and unconstrained optimization problems that is based on natural selection process that mimics biological evaluation. It explores the solution space by using concepts taken from natural genetics and evolution The proposal model to determine the best order quantity theory [13] .

GA starts with an initial set of solutions which is known as materials and twelve months.

a population. The individuals of the population are called The demands on material to this example are given in chromosomes which are evaluated according to a table (1) and first column of the table include the initial predefined fitness function, in our case the total cost .Each inventory levels $V_{i}^{0}$.

chromosome include several genes. The gene represents Table (2) shows the price costs and table (3) shows the an order quantity of item I at time point $\mathrm{j}$ [14]. Anew transportation costs .

generation is created by changing chromosomes in the

Table (1) Material Demands of the Example

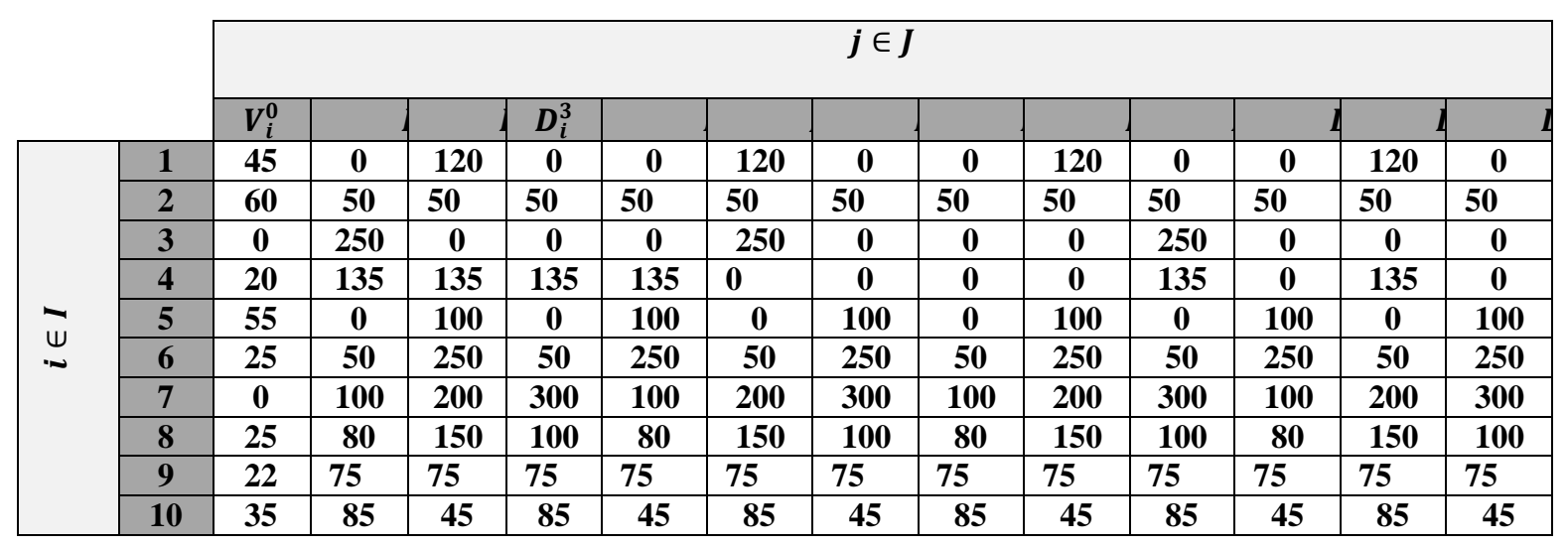

Table(2) The Relation Between Price Costs Per Unit and Material Order Quantity of the Example

\begin{tabular}{|c|c|c|c|c|c|c|c|c|c|}
\hline \multirow{2}{*}{$\begin{array}{c}\text { Material } \\
i \in I\end{array}$} & \multicolumn{9}{|c|}{ Price Costs } \\
\hline & 1 & 2 & 3 & 4 & 5 & 6 & 7 & 8 & 9 \\
\hline \multirow[t]{2}{*}{1} & $1-50$ & $51-100$ & $101-150$ & $151-200$ & 201-250 & & & & \\
\hline & 10 & 9.5 & 9 & 8.5 & 8 & & & & \\
\hline \multirow[t]{2}{*}{2} & $1-100$ & $101-200$ & 201-300 & $301-400$ & $401-500$ & $501-600$ & & & \\
\hline & 25 & 23 & 21 & 19 & 18 & 14 & & & \\
\hline \multirow[t]{2}{*}{3} & $1-100$ & $101-200$ & $201-300$ & 301-400 & $401-500$ & 501-600 & $601-700$ & 701-800 & \\
\hline & 18 & 16.5 & 15 & 13.5 & 12 & 10 & 9 & 7.5 & \\
\hline \multirow[t]{2}{*}{4} & $1-100$ & $101-200$ & $201-300$ & 301-400 & $401-500$ & 501-600 & 601-700 & 701-800 & $\begin{array}{l}\text { 801- } \\
900\end{array}$ \\
\hline & 23 & 22 & 21 & 20 & 19 & 17 & 15 & 13.5 & 12 \\
\hline \multirow[t]{2}{*}{5} & $1-100$ & $101-200$ & 201-300 & 301-400 & $401-500$ & 501-600 & & & \\
\hline & 35 & 32 & 28 & 26 & 23 & 21 & & & \\
\hline \multirow[t]{2}{*}{6} & $1-200$ & 201-400 & 401-600 & 601-800 & 801-1000 & $\begin{array}{l}1001- \\
1200\end{array}$ & $\begin{array}{l}1201- \\
1400\end{array}$ & $\begin{array}{l}1401- \\
1600\end{array}$ & $\begin{array}{l}1601- \\
1800\end{array}$ \\
\hline & 50 & 48 & 44 & 40 & 38 & 36 & 34 & 32 & 30 \\
\hline \multirow[t]{2}{*}{7} & $1-300$ & 301-600 & 601-900 & 901-1200 & $\begin{array}{l}1201- \\
1500\end{array}$ & $\begin{array}{c}1501- \\
1800\end{array}$ & $\begin{array}{l}1801- \\
2100\end{array}$ & $\begin{array}{l}2101- \\
2400\end{array}$ & \\
\hline & 36 & 32 & 30 & 27 & 25 & 22 & 20 & 18 & \\
\hline \multirow[t]{2}{*}{8} & $1-200$ & $201-400$ & 401-600 & 601-800 & $801-1000$ & $\begin{array}{l}1001- \\
1200\end{array}$ & $\begin{array}{l}1201- \\
1400\end{array}$ & & \\
\hline & 18 & 17 & 15 & 12 & 11 & 10 & 8 & & \\
\hline \multirow[t]{2}{*}{9} & $1-200$ & $201-400$ & $401-600$ & 601-800 & $801-1000$ & & & & \\
\hline & 20 & 18 & 16 & 14 & 12 & & & & \\
\hline \multirow[t]{2}{*}{10} & $1-200$ & $201-400$ & 401-600 & 601-800 & $801-1000$ & & & & \\
\hline & 18 & 16 & 15 & 14 & 13 & & & & \\
\hline
\end{tabular}




\section{International Advanced Research Journal in Science, Engineering and Technology}

ISO 3297:2007 Certified

Vol. 3, Issue 8, August 2016

Table (3) Transportation Costs Per Unit of the Example

\begin{tabular}{|c|c|c|c|c|c|c|c|}
\hline \multirow{2}{*}{$\begin{array}{c}\text { Material } \\
\mathrm{i} \in \mathrm{I}\end{array}$} & \multicolumn{7}{|c|}{$\mathbf{r}_{\mathbf{i}}^{\mathbf{m}}-\mathbf{r}_{\mathbf{i}}^{\mathbf{m}-\mathbf{1}}$} \\
\cline { 2 - 8 } & $0-500$ & $500-1000$ & $1000-1500$ & $1500-2000$ & $2000-2500$ & $2500-3000$ & $3000-4000$ \\
\hline 1 & $\mathbf{1 0 0}$ & $\mathbf{9 5}$ & $\mathbf{9 0}$ & $\mathbf{8 5}$ & $\mathbf{8 0}$ & $\mathbf{7 0}$ & $\mathbf{6 0}$ \\
\hline 2 & $\mathbf{2 5 0}$ & $\mathbf{2 3 0}$ & $\mathbf{2 0 0}$ & $\mathbf{1 8 0}$ & $\mathbf{1 7 0}$ & $\mathbf{1 5 0}$ & $\mathbf{1 5 0}$ \\
\hline 3 & $\mathbf{2 0 0}$ & $\mathbf{1 6 5}$ & $\mathbf{1 5 0}$ & $\mathbf{1 3 5}$ & $\mathbf{1 2 0}$ & $\mathbf{1 0 0}$ & $\mathbf{9 0}$ \\
\hline 4 & $\mathbf{2 3 0}$ & $\mathbf{2 2 0}$ & $\mathbf{2 1 0}$ & $\mathbf{2 0 0}$ & $\mathbf{1 8 0}$ & $\mathbf{1 7 0}$ & $\mathbf{1 5 0}$ \\
\hline 5 & $\mathbf{3 0 0}$ & $\mathbf{2 7 0}$ & $\mathbf{2 5 0}$ & $\mathbf{2 4 0}$ & $\mathbf{2 3 0}$ & $\mathbf{2 1 0}$ & $\mathbf{2 0 0}$ \\
\hline 6 & $\mathbf{1 2 0}$ & $\mathbf{1 1 5}$ & $\mathbf{1 0 0}$ & $\mathbf{9 0}$ & $\mathbf{7 5}$ & $\mathbf{7 0}$ & $\mathbf{6 5}$ \\
\hline 7 & $\mathbf{3 0 0}$ & $\mathbf{2 8 0}$ & $\mathbf{2 6 0}$ & $\mathbf{2 4 0}$ & $\mathbf{2 5 0}$ & $\mathbf{2 2 0}$ & $\mathbf{2 0 0}$ \\
\hline 8 & $\mathbf{1 8 0}$ & $\mathbf{1 7 0}$ & $\mathbf{1 5 0}$ & $\mathbf{1 2 0}$ & $\mathbf{1 1 0}$ & $\mathbf{1 0 0}$ & $\mathbf{9 0}$ \\
\hline 9 & $\mathbf{2 0 0}$ & $\mathbf{1 8 0}$ & $\mathbf{1 6 0}$ & $\mathbf{1 4 0}$ & $\mathbf{1 2 0}$ & $\mathbf{1 1 0}$ & $\mathbf{1 0 0}$ \\
\hline 10 & $\mathbf{2 5 0}$ & $\mathbf{2 2 5}$ & $\mathbf{2 0 0}$ & $\mathbf{1 8 0}$ & $\mathbf{1 7 0}$ & $\mathbf{1 6 0}$ & $\mathbf{1 5 0}$ \\
\hline
\end{tabular}

Table (4) and (5) show fixed ordering cost $\mathrm{o}_{i}$ and holding cost $\mathrm{h}_{\mathrm{i}}$ per month respectively .

Table (4) Ordering Cost of the Example

\begin{tabular}{|c|c|c|c|c|c|c|c|c|c|c|}
\hline $\mathrm{i}$ & 1 & 2 & 3 & 4 & 5 & 6 & 7 & 8 & 9 & 10 \\
\hline $\mathrm{o}_{\mathrm{i}}$ & 40 & 35 & 60 & 80 & 90 & 200 & 150 & 120 & 300 & 250 \\
\hline
\end{tabular}

Table (5) Holding Cost of the Example

\begin{tabular}{|c|c|c|c|c|c|c|c|c|c|c|}
\hline $\mathrm{i}$ & 1 & 2 & 3 & 4 & 5 & 6 & 7 & 8 & 9 & 10 \\
\hline $\mathrm{h}_{\mathrm{i}}$ & 4 & 3.5 & 6 & 8 & 9 & 20 & 15 & 12 & 30 & 25 \\
\hline
\end{tabular}

6. SOLUTION OF THE NMERICAL EXAMPLE programming after 300 runs and each run gives various total cost with a various set of order quantities, then The best order quantities for this numerical example can compares them to give best order quantities with minimal be shown in table (6). The solutions are given in Matlab total cost that equal to 2172975 \$.

Table (6) Best Order Quantities

\begin{tabular}{|c|c|c|c|c|c|c|c|c|c|c|c|c|c|}
\hline & \multicolumn{12}{|c|}{$\mathbf{j} \in \mathbf{J}$} \\
\hline & & $Q_{i}^{1}$ & $\overline{Q_{i}^{2}}$ & $\mathbf{Q}_{\mathrm{i}}^{3}$ & $\mathbf{Q}_{i}^{4}$ & $Q_{i}^{5}$ & $Q_{i}^{6}$ & $Q_{i}^{7}$ & $\mathbf{Q}_{i}^{8}$ & $Q_{i}^{9}$ & $Q_{i}^{10}$ & $Q_{i}^{11}$ & $Q_{i}^{12}$ \\
\hline \multirow{10}{*}{$\vec{w}$} & 1 & 75 & 0 & 0 & 0 & 120 & 0 & 0 & 120 & 0 & 0 & 120 & $\mathbf{0}$ \\
\hline & 2 & 0 & 40 & 50 & 50 & 100 & 50 & 50 & 50 & 50 & 50 & 50 & $\mathbf{0}$ \\
\hline & 3 & 250 & $\mathbf{0}$ & $\mathbf{0}$ & 0 & 250 & 0 & 0 & $\mathbf{0}$ & 250 & 0 & 0 & 0 \\
\hline & 4 & 115 & 135 & 135 & 135 & $\mathbf{0}$ & $\mathbf{0}$ & 0 & o & 135 & 0 & 135 & 0 \\
\hline & 5 & $\mathbf{0}$ & 45 & $\mathbf{0}$ & 100 & o & 100 & $\mathbf{0}$ & 100 & 0 & 100 & 0 & 100 \\
\hline & 6 & 25 & 250 & 50 & 250 & 50 & 250 & 50 & 250 & 50 & 250 & 50 & 250 \\
\hline & 7 & 100 & 502 & $\mathbf{0}$ & 98 & 200 & 518 & 0 & 82 & 300 & 100 & 200 & 300 \\
\hline & 8 & 55 & 150 & 100 & 80 & 150 & 100 & 80 & 150 & 100 & 80 & 150 & 100 \\
\hline & 9 & 55 & 75 & 75 & 75 & 75 & 75 & 75 & 75 & 75 & 75 & 75 & 75 \\
\hline & 10 & 50 & 45 & 85 & 45 & 85 & 45 & 85 & 45 & 85 & 45 & 85 & 45 \\
\hline
\end{tabular}

Tables (7) and (8) shows inventory levels $\left(V_{i}^{j}\right)$ and holding costs which are calculated from equtions 4 and 5 ,respectively.

Table (7) Inventory levels

\begin{tabular}{|c|c|c|c|c|c|c|c|c|c|c|c|c|c|c|}
\hline & \multicolumn{13}{|c|}{$\mathbf{j} \in \mathbf{J}$} \\
\hline & & $V_{i}^{0}$ & $V_{i}^{1}$ & $V_{i}^{2}$ & $V_{i}^{3}$ & $V_{i}^{4}$ & $V_{i}^{5}$ & $V_{i}^{6}$ & $V_{i}^{7}$ & $V_{i}^{8}$ & $V_{i}^{9}$ & $V_{i}^{10}$ & $V_{i}^{11}$ & $V_{i}^{12}$ \\
\hline \multirow{5}{*}{$\vec{w}$} & 1 & 45 & 120 & 0 & 0 & 0 & $\mathbf{0}$ & 0 & 0 & 0 & 0 & 0 & 0 & 0 \\
\hline & 2 & 60 & 10 & $\mathbf{0}$ & $\mathbf{0}$ & $\mathbf{0}$ & 50 & 50 & 50 & 50 & 50 & 50 & 50 & $\mathbf{0}$ \\
\hline & 3 & ( & 0 & 0 & 0 & ( & $\mathbf{0}$ & 0 & 0 & 0 & 0 & 0 & ( & ( \\
\hline & 4 & 20 & 0 & $\mathbf{0}$ & $\mathbf{0}$ & $\mathbf{0}$ & $\mathbf{0}$ & $\mathbf{0}$ & 0 & $\mathbf{0}$ & $\mathbf{0}$ & $\mathbf{0}$ & $\mathbf{0}$ & $\mathbf{0}$ \\
\hline & 5 & 55 & 55 & 0 & $\mathbf{0}$ & 0 & $\mathbf{0}$ & $\mathbf{0}$ & 0 & 0 & 0 & 0 & 0 & $\mathbf{0}$ \\
\hline
\end{tabular}


International Advanced Research Journal in Science, Engineering and Technology

ISO 3297:2007 Certified

Vol. 3, Issue 8, August 2016

\begin{tabular}{|c|c|c|c|c|c|c|c|c|c|c|c|c|c|c|}
\hline $\mathbf{6}$ & $\mathbf{2 5}$ & $\mathbf{0}$ & $\mathbf{0}$ & $\mathbf{0}$ & $\mathbf{0}$ & $\mathbf{0}$ & $\mathbf{0}$ & $\mathbf{0}$ & $\mathbf{0}$ & $\mathbf{0}$ & $\mathbf{0}$ & $\mathbf{0}$ & $\mathbf{0}$ \\
\hline $\mathbf{7}$ & $\mathbf{0}$ & $\mathbf{0}$ & $\mathbf{3 0 2}$ & $\mathbf{2}$ & $\mathbf{0}$ & $\mathbf{0}$ & $\mathbf{2 1 8}$ & $\mathbf{1 1 8}$ & $\mathbf{0}$ & $\mathbf{0}$ & $\mathbf{0}$ & $\mathbf{0}$ & $\mathbf{0}$ \\
\hline $\mathbf{8}$ & $\mathbf{2 5}$ & $\mathbf{0}$ & $\mathbf{0}$ & $\mathbf{0}$ & $\mathbf{0}$ & $\mathbf{0}$ & $\mathbf{0}$ & $\mathbf{0}$ & $\mathbf{0}$ & $\mathbf{0}$ & $\mathbf{0}$ & $\mathbf{0}$ & $\mathbf{0}$ \\
\hline $\mathbf{9}$ & $\mathbf{2 2}$ & $\mathbf{2}$ & $\mathbf{2}$ & $\mathbf{2}$ & $\mathbf{2}$ & $\mathbf{2}$ & $\mathbf{2}$ & $\mathbf{2}$ & $\mathbf{2}$ & $\mathbf{2}$ & $\mathbf{2}$ & $\mathbf{2}$ & $\mathbf{2}$ \\
\hline $\mathbf{1 0}$ & $\mathbf{3 5}$ & $\mathbf{0}$ & $\mathbf{0}$ & $\mathbf{0}$ & $\mathbf{0}$ & $\mathbf{0}$ & $\mathbf{0}$ & $\mathbf{0}$ & $\mathbf{0}$ & $\mathbf{0}$ & $\mathbf{0}$ & $\mathbf{0}$ & $\mathbf{0}$ \\
\hline
\end{tabular}

Table (8) Holding Costs

\begin{tabular}{|c|c|c|c|c|c|c|c|c|c|c|c|c|c|c|c|}
\hline & \multicolumn{13}{|c|}{$\mathbf{j} \in \mathbf{J}$} & \multirow{2}{*}{$\begin{array}{l}\text { Holding } \\
\text { Costs }\end{array}$} \\
\hline & & (0 & 1 & 2 & 3 & 4 & 5 & 6 & 7 & 8 & 9 & 10 & 11 & 12 & \\
\hline \multirow{10}{*}{$\underset{w}{.}$} & 1 & 180 & 480 & 0 & 0 & 0 & 0 & O & O & O & O & O & O & 0 & 660 \\
\hline & 2 & 210 & 35 & 0 & 0 & 0 & 175 & 175 & 175 & 175 & 175 & 175 & 175 & $\mathbf{0}$ & 1470 \\
\hline & 3 & $\mathbf{0}$ & 0 & 0 & 0 & $\mathbf{0}$ & 0 & 0 & 0 & 0 & $\mathbf{0}$ & 0 & $\mathbf{0}$ & $\mathbf{0}$ & 0 \\
\hline & 4 & 160 & $\mathbf{0}$ & 0 & 0 & O & 0 & 0 & 0 & 0 & 0 & 0 & $\mathbf{0}$ & 0 & 160 \\
\hline & 5 & 495 & 495 & 0 & 0 & $\mathbf{0}$ & 0 & 0 & 0 & $\mathbf{0}$ & 0 & 0 & $\mathbf{0}$ & $\mathbf{0}$ & 990 \\
\hline & 6 & 500 & 0 & 0 & 0 & 0 & 0 & 0 & 0 & 0 & 0 & 0 & 0 & 0 & 500 \\
\hline & 7 & $\mathbf{0}$ & 0 & 4530 & 30 & 0 & 0 & 3270 & 1770 & 0 & $\mathbf{0}$ & 0 & $\mathbf{0}$ & $\mathbf{0}$ & 9600 \\
\hline & 8 & 300 & 0 & 0 & 0 & $\mathbf{0}$ & 0 & 0 & 0 & $\mathbf{0}$ & $\mathbf{0}$ & 0 & 0 & 0 & 300 \\
\hline & 9 & 660 & 60 & 60 & 60 & 60 & 60 & 60 & 60 & 60 & 60 & 60 & 60 & 60 & 1380 \\
\hline & 10 & 875 & O & $\mathbf{0}$ & $\mathbf{0}$ & $\mathbf{0}$ & $\mathbf{0}$ & $\mathbf{0}$ & $\mathbf{0}$ & $\mathbf{0}$ & $\mathbf{0}$ & $\mathbf{0}$ & $\mathbf{0}$ & $\mathbf{0}$ & 875 \\
\hline \multicolumn{15}{|c|}{ Total Holding Costs } & 15935 \\
\hline
\end{tabular}

Tables (8),(9) and (10) show the ordering costs, purchasing costs and transportation costs for all items in a year which are calculated from equtions 6 and 7 and 8,respectively.

Table (8) Ordering Costs

\begin{tabular}{|c|c|c|c|c|c|c|c|c|c|c|c|c|c|c|}
\hline & \multicolumn{12}{|c|}{$\mathbf{j} \in \mathbf{J}$} & \multirow{2}{*}{$\begin{array}{c}\begin{array}{c}\text { Ordering } \\
\text { Costs }\end{array} \\
\end{array}$} \\
\hline & & 1 & 2 & 3 & 4 & 5 & 6 & 7 & 8 & 9 & 10 & 11 & 12 & \\
\hline & 1 & 3000 & 0 & 0 & $\mathbf{0}$ & 4800 & 0 & 0 & 4800 & 0 & 0 & $\begin{array}{c}480 \\
0\end{array}$ & 0 & \\
\hline & 2 & O & 1400 & 1750 & 1750 & 3500 & $\begin{array}{c}175 \\
0\end{array}$ & $\begin{array}{c}175 \\
0\end{array}$ & 1750 & 1750 & $\begin{array}{c}175 \\
0\end{array}$ & $\begin{array}{c}175 \\
0\end{array}$ & 0 & 18900 \\
\hline & 3 & 15000 & (0 & ( & ( & 15000 & 0 & 0 & 0 & 15000 & 0 & 0 & ( & 45000 \\
\hline & 4 & 9200 & 10800 & 10800 & 10800 & 0 & 0 & 0 & 0 & 10800 & 0 & $\begin{array}{c}108 \\
00\end{array}$ & 0 & 63200 \\
\hline & 5 & 0 & 4050 & o & 9000 & 0 & $\begin{array}{c}900 \\
0\end{array}$ & o & 9000 & 0 & $\begin{array}{c}900 \\
0\end{array}$ & 0 & $\begin{array}{c}900 \\
0\end{array}$ & 49050 \\
\hline ש & 6 & 5000 & 50000 & 10000 & 50000 & 10000 & $\begin{array}{c}500 \\
00\end{array}$ & $\begin{array}{c}100 \\
00\end{array}$ & 50000 & 10000 & $\begin{array}{c}500 \\
00\end{array}$ & $\begin{array}{c}100 \\
00\end{array}$ & $\begin{array}{c}500 \\
00\end{array}$ & 355000 \\
\hline & 7 & 15000 & 75300 & $\mathbf{0}$ & 14700 & 30000 & $\begin{array}{c}777 \\
00\end{array}$ & 0 & $\begin{array}{c}1230 \\
0\end{array}$ & 45000 & $\begin{array}{c}150 \\
00\end{array}$ & $\begin{array}{c}300 \\
\mathbf{0 0}\end{array}$ & $\begin{array}{c}450 \\
00\end{array}$ & 360000 \\
\hline & 8 & 6600 & 18000 & 12000 & 9600 & 18000 & $\begin{array}{c}120 \\
00\end{array}$ & $\begin{array}{c}960 \\
0\end{array}$ & 18000 & 12000 & $\begin{array}{c}960 \\
0\end{array}$ & $\begin{array}{l}180 \\
00\end{array}$ & $\begin{array}{c}120 \\
00\end{array}$ & 155400 \\
\hline & 9 & 16500 & 22500 & 22500 & 22500 & 22500 & $\begin{array}{l}225 \\
00 \\
\end{array}$ & $\begin{array}{l}225 \\
00 \\
\end{array}$ & 22500 & 22500 & $\begin{array}{l}225 \\
00 \\
\end{array}$ & $\begin{array}{l}225 \\
00 \\
\end{array}$ & $\begin{array}{l}225 \\
00 \\
\end{array}$ & 264000 \\
\hline & 10 & $\overline{12500}$ & 11250 & 21250 & 11250 & 21250 & $\begin{array}{c}112 \\
50\end{array}$ & $\begin{array}{c}212 \\
50\end{array}$ & 11250 & 21250 & $\begin{array}{c}112 \\
50\end{array}$ & $\begin{array}{c}212 \\
50\end{array}$ & $\begin{array}{c}112 \\
50\end{array}$ & 186250 \\
\hline & & & & & & & & & & & & & & 1514200 \\
\hline
\end{tabular}

Table (9) Purchasing Costs

\begin{tabular}{|c|c|c|c|c|c|c|c|c|c|c|c|c|c|}
\hline & \multicolumn{12}{|c|}{$\mathbf{j} \in \mathbf{J}$} & \multirow{2}{*}{$\begin{array}{l}\text { Purchasi } \\
\text { ng Costs }\end{array}$} \\
\hline & 1 & 2 & 3 & 4 & 5 & 6 & 7 & 8 & 9 & 10 & 11 & 12 & \\
\hline 1 & 712 & 0 & 0 & 0 & 1080 & 0 & 0 & 1080 & 0 & $\mathbf{0}$ & 1080 & 0 & 3952 \\
\hline 2 & O & 1000 & 1250 & 2300 & 1250 & 1250 & 1250 & 1250 & 1250 & 1250 & 1250 & 0 & 13300 \\
\hline 3 & 3750 & 0 & 0 & 0 & 3750 & $\mathbf{0}$ & 0 & 0 & 3750 & 0 & 0 & 0 & 11250 \\
\hline 4 & 2530 & 2970 & 2970 & 2970 & $\mathbf{0}$ & 0 & 0 & $\mathbf{0}$ & 2970 & 0 & 2970 & 0 & 17380 \\
\hline 5 & 0 & 1575 & 0 & 3200 & 0 & 3200 & 0 & 3200 & $\mathbf{0}$ & 3200 & 0 & 3200 & 17575 \\
\hline 6 & 1250 & 12000 & 2500 & 1200 & 2500 & 12000 & 2500 & 1200 & 2500 & 1200 & 2500 & 1200 & 85750 \\
\hline
\end{tabular}




\section{International Advanced Research Journal in Science, Engineering and Technology}

ISO 3297:2007 Certified

Vol. 3, Issue 8, August 2016

\begin{tabular}{|c|c|c|c|c|c|c|c|c|c|c|c|c|c|}
\hline & & & & $\mathbf{0}$ & & & & $\mathbf{0}$ & & $\mathbf{0}$ & & $\mathbf{0}$ & \\
\hline 7 & $\mathbf{3 6 0 0}$ & $\mathbf{1 6 0 6 4}$ & $\mathbf{0}$ & $\mathbf{3 5 2 8}$ & $\mathbf{7 2 0 0}$ & $\mathbf{1 6 5 7 6}$ & $\mathbf{0}$ & $\mathbf{2 9 5 2}$ & $\mathbf{1 0 8 0}$ & $\mathbf{3 6 0 0}$ & $\mathbf{7 2 0 0}$ & $\begin{array}{c}\mathbf{1 0 8 0} \\
\mathbf{0}\end{array}$ & $\mathbf{8 2 3 2 0}$ \\
\hline $\mathbf{8}$ & $\mathbf{9 9 0}$ & $\mathbf{2 7 0 0}$ & $\mathbf{1 8 0 0}$ & $\mathbf{1 4 4 0}$ & $\mathbf{2 7 0 0}$ & $\mathbf{1 8 0 0}$ & $\mathbf{1 4 4 0}$ & $\mathbf{2 7 0 0}$ & $\mathbf{1 8 0 0}$ & $\mathbf{1 4 4 0}$ & $\mathbf{2 7 0 0}$ & $\mathbf{1 8 0 0}$ & $\mathbf{2 3 3 1 0}$ \\
\hline $\mathbf{9}$ & $\mathbf{1 1 0 0}$ & $\mathbf{1 5 0 0}$ & $\mathbf{1 5 0 0}$ & $\mathbf{1 5 0 0}$ & $\mathbf{1 5 0 0}$ & $\mathbf{1 5 0 0}$ & $\mathbf{1 5 0 0}$ & $\mathbf{1 5 0 0}$ & $\mathbf{1 5 0 0}$ & $\mathbf{1 5 0 0}$ & $\mathbf{1 5 0 0}$ & $\mathbf{1 5 0 0}$ & $\mathbf{1 7 6 0 0}$ \\
\hline 10 & $\mathbf{9 0 0}$ & $\mathbf{8 1 0}$ & $\mathbf{1 5 3 0}$ & $\mathbf{8 1 0}$ & $\mathbf{1 5 3 0}$ & $\mathbf{8 1 0}$ & $\mathbf{1 5 3 0}$ & $\mathbf{8 1 0}$ & $\mathbf{1 5 3 0}$ & $\mathbf{8 1 0}$ & $\mathbf{1 5 3 0}$ & $\mathbf{8 1 0}$ & $\mathbf{1 3 4 1 0}$ \\
\hline \multicolumn{10}{|c|}{ Total Purchasing Costs } \\
\hline \multicolumn{10}{|c|}{}
\end{tabular}

Table (10) Transportation Costs

\begin{tabular}{|c|c|c|c|c|c|c|c|c|c|c|c|c|c|c|}
\hline & \multicolumn{12}{|c|}{$\mathbf{j} \in \mathbf{J}$} & \multirow{2}{*}{$\begin{array}{c}\text { Transp } \\
\text { ortation } \\
\text { Costs } \\
\end{array}$} \\
\hline & & 1 & 2 & 3 & 4 & 5 & 6 & 7 & 8 & 9 & 10 & 11 & 12 & \\
\hline & 1 & 7500 & 0 & 0 & 0 & 12000 & 0 & 0 & 12000 & 0 & 0 & $\begin{array}{c}120 \\
00\end{array}$ & 0 & 43500 \\
\hline & 2 & $\mathbf{0}$ & $\begin{array}{c}1000 \\
0\end{array}$ & 12500 & 12500 & 12500 & $\begin{array}{l}125 \\
00 \\
\end{array}$ & 12500 & 12500 & 12500 & 12500 & $\begin{array}{l}125 \\
00 \\
\end{array}$ & $\mathbf{0}$ & 135000 \\
\hline & 3 & 50000 & 0 & 0 & $\mathbf{0}$ & 50000 & 0 & $\mathbf{0}$ & 0 & 50000 & 0 & 0 & 0 & 150000 \\
\hline & 4 & $\mathbf{3 3 3}$ & 391 & 391 & 391 & $\mathbf{0}$ & 0 & 0 & 0 & 391 & 0 & 391 & 0 & 2288 \\
\hline & 5 & 0 & 146 & 0 & 325 & 0 & 325 & 0 & 325 & $\mathbf{0}$ & 325 & 0 & 325 & 1771 \\
\hline$\underset{\sim}{ \pm}$ & 6 & 100 & 1000 & 200 & 1000 & 200 & $\begin{array}{c}100 \\
0\end{array}$ & 200 & 1000 & 200 & 1000 & 200 & $\begin{array}{c}100 \\
0\end{array}$ & 7100 \\
\hline & 7 & 290 & 1290 & 0 & 284 & 580 & $\begin{array}{c}133 \\
1\end{array}$ & 0 & 238 & 870 & 290 & 580 & 870 & 6623 \\
\hline & 8 & 179 & 488 & 325 & 260 & 488 & 325 & 260 & 488 & 325 & 260 & 4488 & 325 & 4211 \\
\hline & 9 & 220 & 300 & 300 & 300 & 300 & 300 & 300 & 300 & 300 & 300 & 300 & 300 & 3520 \\
\hline & $\begin{array}{l}1 \\
0\end{array}$ & 200 & 180 & 340 & 180 & 340 & 180 & 340 & 180 & 340 & 180 & 340 & 180 & 2980 \\
\hline
\end{tabular}

\section{CONCLUSION}

We have described model for determining the best order quantity of materials with minimum total cost from suppliers to any company. The cost in this paper consist from purchasing, ordering, holding and transportation costs. Ordering and holding costs are considered costs constant for each unit from materials, purchasing and transportation costs are considered variable costs. In this case, whenever increasing the quantity of materials lead to decrease the cost of the one unit. The results of this model explained its ability on assist the companies to determine the right order quantity at the right time with minimum total cost and uses with different time period such as days and months, etc.

\section{REFERENCES}

[1] Demirtas, E. A, and Ö. Üstün (2008) "An Integrated Multi objective Decision Making Process for Supplier Selection and Order Allocation." Omega V(36) ,pp( 76-90).

[2] Davari, S., M. H. F. Zarandi, and I. B. Turksen (2008) "Supplier Selection in A Multi-item/multi-supplier Environment." Institute of Electrical and Electronics Engineers.

[3] Sarker B.R., Jamal A.M.M., Mondal S.(2008) Optimal Batch Sizing in a Multi-stage Production System with Rework Consideration, European Journal of Operational Research 184, 915-929.

[4] Wadhwa, V., and A. Ravindran (2010) "Multi-objective Supplier Selection Models." Proceedings of the Industrial Engineering Research Conference.

[5] Araújo M.C. and Alencar D.(2014) integrated model for supplier selection and performance evaluation, south African journal of industrial engineering august, Vol 26(2) pp. (41-55).
[6] Monczka, Robert B. Handfield, Larry C. Giunipero, James L. Patterson (2009) Purchasing and Supply Chain Management, four edition.

[7] Eiliat , H. ( 2013) ,Optimization of Operational Cost for a Single Supplier - Manufacturer Supply Chain, Master thesis, university of Windsor Industrial and manufacturing systems engineering.

[8] Bredenkamp, F.V. ( 2005) ,The Development of a Genetic Just-InTime Supply Chain Optimization Sostware Tool, Master thesis , Unversity of Stellenbosch, Industrial Engineering .

[9] Holstein, J. \& Olofsson, A. (2009)"Inventory Control - At Maintenance Unit Tetra Pak in Lund." Thesis. Lund University, Lund University - Production Management, http://www.pm.lth.se/ fileadmin/pm/Exjobb/Exjobb.

[10] Axsäter, S. (2006). Inventory Control, International Series in Operations Research \& Management Science, 2nd ed, New York: Springer.

[11] Eiliat , H. ( 2013) ,Optimization of Operational Cost for a Single Supplier -Manufacturer Supply Chain, Master thesis, university of Windsor Industrial and manufacturing systems engineering

[12] Burger F. ( 2003 ), The impact of warehousing and transportation on supply chain effectiveness, Master thesis , Rand Afrikaans University .

[13] Pinedo, M. (2002). Scheduling: Theory, Algorithms and Systems, 2nd ed, Prentice Hall, Englewood Cliffs, NJ.

[14] Zhu, X. and Wilhelm, W.E. (2006). Scheduling and lot sizing with sequence-dependent setup: A literature review, IIE Transactions V (38), pp (987-1007). 